Vincent Pol University in Lublin,

Poland

\title{
COPING WITH DIFFICULT SITUATIONS BY TOURISM WORKERS (FOREIGN EXCURSION GUIDES)
}

\begin{abstract}
Objectives: The aim of the study was to identify the preferred means of coping with stress among the workers of tourism industry, specifically, foreign excursion guides. The research problem was formulated in the form of the following question: What ways of dealing with stressful situations are preferred by the workers of tourism industry - foreign excursion guides?

Material and methods: The subject of the study was a group of 31 practicing guides. The chosen research method was a diagnostic poll. The adopted research tool was the Ways of Coping Questionnaire developed by S. Folkman and R. Lazarus.

Results: Results were divided regarding sex and place of residence. Average results of men are slightly higher for the following strategies: "Desires" $(M=7,33 ; W=6,50)$, "Passive attitude" ( $M=7,66 ; \mathrm{W}=6,25)$, "Positive attitude" $(M=5,40 ; \mathrm{W}=4,00)$, "Blaming oneself" ( $M=4,29 ; W=4,00)$ and "Retiring into oneself" $(M=3,96 ; W=2,75)$. Women, in turn, handle better such strategies as "Solving problems" (W=18,50; $M=16,96)$, "Seeking social support" (W=11,25; M=9,40) and "Reduction of tension" (W=4,50; $\mathrm{M}=3,14)$. In all the cases, however, no significant differences can be noticed.

Conclusions: The subjects of the study do not seem to prefer any of the eight analyzed ways of coping with problematic situations, which is confirmed by the average results obtained for all the strategies. More specifically, however, it can be noticed that men tend to employ the strategy of rational approach to problems more than women. The analyses also show that the variables such as sex and place of living do not significantly influence the subjects' preferences with respect to the ways of coping with difficult situations.
\end{abstract}

KEYWORDS: stress, tourism, coping with, excursion guide, difficult situations. 


\section{SUMmary}

Modern market of tourism services is getting more and more professional and demanding. The competition to get a client is getting more and more fierce. As a result, the people working in tourism have to face new challenges, which entail more difficult, problematic and stressful situations.

The aim of the study was to identify the preferred means of coping with stress among the workers of tourism industry, specifically, the foreign excursion guides. The subject of the study was a group of 31 practicing guides. The chosen research method was a diagnostic poll. The adopted research tool was the Ways of Coping Questionnaire developed by S. Folkman and R. Lazarus.

The analysis showed that the subjects do not prefer any of the 8 ways of coping with difficult situations. All the results can be seen as average.

\section{INTRODUCTION}

The employees in tourism industry more and more often have to work in difficult, stressful conditions. What is more, the people they work with can be hard to get on with. The clients in tourism are increasingly aware and demanding, which makes the market increasingly competitive. Meeting the requirements of the profession involves high emotional involvement on the part of the workers, who frequently encounter stressful situations. It may turn out to be destructive if they cannot meet their clients' and bosses' expectations.

Every human being has an individual, internal system of reactions to problematic, difficult and stressful situations. Such events change an individual and his or her identity, becoming in this way a part of one's individual development. They also make it necessary to make choices, which in the long run modify both one's individual and collective identity. Difficult situations are a part of human life, but everybody perceives them differently and chooses different techniques to cope with them. Stress, which is understood as a reaction to external and internal stimuli, is a complex system of environmental, situational and subjective factors.

The problem of stress is interdisciplinary in nature. As such, it has been of interest to doctors, psychologists, educationalists, anthropologists, biologists, 
sociologists and others. The consequence of such interest is multidimensional approach to the topic.

The forefathers of stress studies include Claude Bernard, who came up with the rule that the stability of the internal environment is the condition for staying alive, and Walter B. Cannon - the creator of the theory of homeostasis. In medicine, however, the notion of stress was first used in 1936 by a Canadian professor Hans Selye, whose theory constituted a continuation of the biological conceptions of stress (after: D. WosikKawala, 2013, p. 88).

In the literature, there are numerous conceptions of stress - its origins, influences and ways of coping with it. One of the first such conceptions was created by H. Selye (after: J.F. Terelak, 2008), who on the basis of the studies of humans in disadvantageous conditions noticed that organisms react to them with a group of changes, increased nervous tension and emotional agitation. According to the author, stress is a "non-specific reaction of an organism to all the imposed requirements" (p. 27). Selye claims (after: J. Strelau, 2000, p. 94) that the reactions to the disadvantageous factors, the so-called stressors, can be adaptive in character. As such, they can take the form of local adaptation syndrome comprising specific reactions to the stressor, or general adaptation syndrome including general, non-specific responses that are not connected with the nature of the negative stimulus that is the source of stress. The author emphasizes the fact that stress is a natural biological reaction of an organism, a physiological phenomenon connected to life processes of every human being. It is a response to everyday, both positive and negative, situations, challenges and changes.

Among the classical theories of stress, it is worth mentioning the theory of Irwing L. Janis (after: I. Heszen-Niejodek, 2000), who defined psychological stress as "a change in the environment which typically, that is for an average person, causes high level of emotional tension which, in turn, disturbs normal reactions" (p. 11). The author of the definition points at both the stressful situation described by means of stimuli causing the disturbances of behaviors, and the response to stress, which is understood as any change in behavior, feelings, attitudes caused by a stressful situation (D. Wosik-Kawala, 2013, p. 89). 
Another theory of stress was developed by Richard S. Lazarus and Susan Folkman (after: J. Strelau, A. Jaworowska, K. Wrześniewski, P. Szczepaniak, 2005, p. 6). According to this conception, the psychological stress is just a special type of relation between a person and the environment, where the latter is perceived as straining or exceeding a person's supplies and threatening his or her well-being. What is highlighted here is the subject's assessment which determines whether a relation is stressful or not. Stress itself is seen as a kind of transaction, which means that the perception of threat depends partially on the situation and on how an individual contributes to it. It is emphasized that the way in which the knowledge of the world is represented and organized by a person influences the assessment of a given situation. According to I. Heszen-Niejodek (2000, p. 470), the relational conception of stress accounts for the fact that subjective assessment by a participant of a situation, rather than objective factors, determines whether a situation is stressful or not. These factors make this conception the theoretical basis of the following analyses.

The factors that induce stress, the so-called stressors, can vary but all of them cause essentially identical, biological response.

A stressed person is motivated to take actions that would allow him or her to regain the balance between situational demands and the abilities to meet them. This activity is referred to as „coping”. This notion applies to a wide range of actions comprising all kinds of effort, both cognitive and behavioral, taken by a subject with a view to meet external and internal demands of a situation. The process of coping, in this case, amounts to take actions aiming at overcoming stress (K. Bargiel-Matusiewicz, Z. Podbielski, A. Klasik, 2004, p. 189).

The term "coping" has three complementing meanings. It can be seen as a process, strategy or style.

The most famous conception of coping with stressful situations was proposed by R.S. Lazarus and S. Folkman (after: I. Heszen-Niejodek, 2000, p. 479-480). They distinguished four basic categories of coping, which represent the diversity of human behavior under the influence of stress:

1) immediate actions (the category comprises all the activities, except cognitive, which aim at overcoming stress), 
2) refraining from action (in some situations, it is more beneficial to refrain from certain activities; it applies especially to the actions that could, in given circumstances, disturb the process of coping with stress),

3) searching for information (this strategy involves an analysis of the situation with the view to increase knowledge useful for the optimization of further remedial actions; additional information increase the probability of taking into account all the important aspects of the situation, which makes it possible to make rational decisions),

4) intrapsychological processes (their usual aim is to cheer a person up by reducing or minimizing negative emotions; one type of such processes are the defense mechanisms).

According to R.S. Lazarus and S. Folkman (after: J. Strelau, B. Zawadzki, W. Oniszczenko, A. Sobolewski, A. Bieniek, 2004, p. 222), the remedial activities undertaken by an individual may have two functions. The first of them is coping focused on a problem. It is an instrumental, task-oriented function that aims at is improving the subject's relation with the environment. The second one is self-regulation of emotions, which eases tension and alleviates negative emotional states. It needs to be stressed that both functions are completely independent. As a result, in the course of analyzing a stressful situation, it can be noticed how they intervene and interact. In some cases, one form of coping can serve both functions, in others, the functions are realized alternately, complementing each other in the long run. It applies, among others, to the situation of examinational stress, where individual phases can be identified. Their requirements promote positive actions that often serve different functions. It is also possible that one form of coping serves just one function and remains neutral towards the other, in which case the emotional state improves but the objective situation of an individual does not. Finally, a given way of coping with stress can foster the realization of one function and hinder, or even prevent, the fulfillment of the other.

\section{Methodology}

The subject matter of the present research was the ways of coping with stressful situations by the employees in tourism industry - foreign excursion guides. 
The aim of the research was an attempt to establish the employees' preferred ways of coping with stressful situations. The research problem was formulated in the form of the following question: What ways of dealing with stressful situations are preferred by the workers of tourism industry - foreign excursion guides?

As the research was diagnostic in character, no hypotheses were formulated (S. Nowak; M. Łobocki, 2007).

Answering the research question was possible thanks to the method of diagnostic poll - a survey technique in which "information is gathered by means of completing, usually by the subjects themselves, specialized questionnaires that are characterized by high level of standardization, in or without the presence of the researcher" (T. Pilch, 1998, p. 86).

The research tool was Ways of Coping Questionnaire (WCQ) developed by S. Folkman and R. Lazarus (1984). It is made up of 66 statements referring to exemplary situations. In order to answer the questions, a person has to recall a stressful situation that was difficult or problematic and that required much effort to overcome. Before giving an answer, a person has to think about the details of the situation such as the place where it happened, the participants, the reactions and why it was important. Having thought about it, a person gives an answer by cycling the right number on the four-point scale. The meanings of the points are the following:

0 - not applied

1 - applied to a small extent

2 - applied to a large extent

3 - applied exactly

The questionnaire contains 8 following scales (ways of coping): solving problems, desire, objectivity, social support, positive attitude, blaming oneself, reduction of tension, retiring into oneself (J. Kirenko 1998).

The study was conducted in January 2017 and included 46 tourism industry workers, foreign excursion guides, in Lublin. After the study, all the questionnaires were verified in order to qualify them for further quantitative and qualitative analyses. As a result of the procedure, 31 questionnaires were selected.

For the purpose of the analysis, according to the procedure developed by J. Brzezinski (1980), boundary values for each strategy of dealing with were established. 
Table 1.

Results

\begin{tabular}{|c|c|c|c|c|}
\hline \multirow{2}{*}{ Variable } & \multirow{2}{*}{ Range } & \multicolumn{3}{|c|}{ Result } \\
\cline { 3 - 5 } & & Low & Average & High \\
\hline Solving problems & $0-33$ & $0-8$ & $9-25$ & $26-33$ \\
\hline Desires & $0-15$ & $0-4$ & $5-11$ & $12-15$ \\
\hline Objectivity & $0-18$ & $0-4,5$ & $4,6-13,5$ & $13,6-18$ \\
\hline Seeking social support & $0-21$ & $0-5$ & $6-15$ & $16-21$ \\
\hline Possitive attitude & $0-12$ & $0-3$ & $4-9$ & $10-12$ \\
\hline Blaming oneself & $0-9$ & $0-2$ & $3-7$ & $8-9$ \\
\hline Reduction of tension & $0-9$ & $0-2$ & $3-7$ & $8-9$ \\
\hline Retiring into oneself & $0-9$ & $0-2$ & $3-7$ & $8-9$ \\
\hline
\end{tabular}

Own elaboration

\section{Results}

The majority of the subjects were men $-87 \%$, which means that one subject in eight was a woman $-13 \%$. Most subjects live in cities $(61,3 \%)$, the rest, that is slightly above one third, lives in village communities $(38,7 \%)$. When the professional experience is taken into account, it turns out that the biggest group $(35,5 \%)$ were the people with 6-10 years of experience. The second group $(22,6 \%)$ was the people with11-15 years of experience, $9,7 \%$ of subject claimed to have 1-5 years of experience and 3,2\% had the biggest experience of 21-25 years. Apart from that, all the subjects claim to have higher education.

When answering the research question, the first step was to compile the data from the Lazarus and Folkman's WCQ (tables 2-9). The second step was a comparative analysis using a t-Student's test including demographic variables such as sex and place of living (tables 9-11). 
Table 2.

Ways of coping with respect to the "Solving problems" variable

\begin{tabular}{|c|c|c|c|c|c|c|}
\hline \multirow{2}{*}{ Results } & \multicolumn{4}{|c|}{ Sex } \\
\cline { 2 - 7 } & \multicolumn{2}{|c|}{ Women } & \multicolumn{2}{c|}{ Men } & \multicolumn{2}{c|}{ Total } \\
\cline { 2 - 7 } & $\mathrm{N}$ & $\%$ & $\mathrm{~N}$ & $\%$ & $\mathrm{~N}$ & $\%$ \\
\hline Low result & 0 & 0,0 & 1 & 3,2 & 1 & 3,2 \\
\hline Average result & 4 & 12,9 & 24 & 77,4 & 28 & 90,3 \\
\hline High Result & 0 & 0,0 & 2 & 6,5 & 2 & 6,5 \\
\hline Total & 4 & 12,9 & 27 & 87,1 & 31 & 100,0 \\
\hline
\end{tabular}

The analysis of the data presented in Table 2 shows that all the women that took part in the study $(12,9 \%)$ and the majority of men $(77,4 \%)$ got an average result with respect to the "Solving problems" strategy, which means that their approach is rather rational. It can be said that they handle difficulties averagely, but they don't employ all their resources. They tend to react emotionally but their behavior is adequate to the situation. What is more, 6,5\% of men got high results for this strategy, which means that this group copes with difficulties very well. These people make an effort and strive to get what they want. Only one person $(3,7 \%)$ got a low result, which shows that he does not choose this strategy in problematic situations.

Table 3.

Ways of coping with respect to the „Desires” variable

\begin{tabular}{|c|c|c|c|c|c|c|}
\hline \multirow{2}{*}{ Results } & \multicolumn{9}{|c|}{ Sex } \\
\cline { 2 - 7 } & \multicolumn{2}{|c|}{ Women } & \multicolumn{2}{c|}{ Men } & \multicolumn{2}{c|}{ Total } \\
\cline { 2 - 7 } & $\mathrm{N}$ & $\%$ & $\mathrm{~N}$ & $\%$ & $\mathrm{~N}$ & $\%$ \\
\hline Low result & 1 & 3,2 & 5 & 16,1 & 6 & 19,4 \\
\hline Average result & 3 & 9,7 & 19 & 61,3 & 22 & 71,0 \\
\hline High Result & 0 & 0,0 & 3 & 9,7 & 3 & 9,7 \\
\hline Total & 4 & 12,9 & 27 & 87,1 & 31 & 100,0 \\
\hline
\end{tabular}


On the "Desires" scale, over a half of women $(9,7 \%)$ and two thirds of men $(61,3 \%)$ got an average result (Table 3$)$. Low results were obtained by every fourth woman $(3,2 \%)$ and almost every fifth man $(16,1 \%)$. Only $9,7 \%$ men got high results. These results show that the majority (71\%) of the tested foreign excursion guides are moderately active when it comes to taking specific actions. They do not get involved completely in searching and finding new solutions. This strategy, however, is preferred by every fourth woman $(3,2 \%)$ and almost every fifth man $(16,1 \%)$. While facing with a difficult situation, they take actions and search for new solutions. The situation is different with the people who got high results $(9,7 \%)$. When they are faced with a problem, they are passive, try to escape from the reality and look for support in the dream world.

Table 4.

Ways of coping with respect to the "Objectivity" variable

\begin{tabular}{|c|c|c|c|c|c|c|}
\hline \multirow{2}{*}{ Results } & \multicolumn{9}{|c|}{ Sex } \\
\cline { 2 - 7 } & \multicolumn{2}{|c|}{ Women } & \multicolumn{2}{c|}{ Men } & \multicolumn{2}{c|}{ Total } \\
\cline { 2 - 7 } & N & $\%$ & N & $\%$ & N & $\%$ \\
\hline Low result & 1 & 3,2 & 4 & 12,9 & 5 & 16,1 \\
\hline Average result & 3 & 9,7 & 22 & 71,0 & 25 & 80,6 \\
\hline High Result & 0 & 0,0 & 1 & 3,2 & 1 & 3,2 \\
\hline Total & 4 & 12,9 & 27 & 87,1 & 31 & 100,0 \\
\hline
\end{tabular}

On the basis of the data presented in Table 4, it can be inferred that when it comes to the „Objectivity” strategy, the majority of women $(9,7 \%)$ and men (71\%) got average results. Every fourth woman (3,2\%) and every fourth man $(12,9 \%)$ got a low result and only $3,2 \%$ men got high results. It can, therefore, be assumed that the majority of subjects $(80,6 \%)$ makes use of this strategy on an average level, which is not entirely commonsensical approach to solving problems. An entirely commonsensical approach is adopted by only one man $(3,2 \%)$. The others ascribe their failures in difficult situations to irrational reasons. 
Table 5.

Ways of coping with respect to the „Seeking social support" variable

\begin{tabular}{|c|c|c|c|c|c|c|}
\hline \multirow{2}{*}{ Results } & \multicolumn{6}{|c|}{ Sex } \\
\cline { 2 - 7 } & \multicolumn{2}{|c|}{ Women } & \multicolumn{2}{c|}{ Men } & \multicolumn{2}{c|}{ Total } \\
\cline { 2 - 7 } & N & $\%$ & N & $\%$ & N & $\%$ \\
\hline Low result & 0 & 0,0 & 5 & 16,1 & 5 & 16,1 \\
\hline Average result & 4 & 12,9 & 20 & 64,5 & 24 & 77,4 \\
\hline High Result & 0 & 0,0 & 2 & 6,5 & 2 & 6,5 \\
\hline Total & 4 & 12,9 & 27 & 87,1 & 31 & 100,0 \\
\hline
\end{tabular}

When analyzing the data in Table 5, it can be noticed that all the women $(12,9 \%)$ and the majority of men $(64,5 \%)$ got average results for the strategy "Seeking social support". It means that in emergencies they do not always, or seldom, look for other people's support, advice, acceptation or simply contact with them. The people who got high results $(6,5 \%)$ are much more determined. They willingly look for contacts with others with the view to get their advice and support. The people who got low results, that is every fifth man $(16,1 \%)$, do not behave like that as they usually seek support in supernatural forces, for instance prayer.

Table 6.

Ways of coping with respect to the "Positive attitude" variable

\begin{tabular}{|c|c|c|c|c|c|c|}
\hline \multirow{2}{*}{ Results } & \multicolumn{9}{|c|}{ Sex } \\
\cline { 2 - 7 } & \multicolumn{2}{|c|}{ Women } & \multicolumn{2}{c|}{ Men } & \multicolumn{2}{c|}{ Total } \\
\cline { 2 - 7 } & $\mathrm{N}$ & $\%$ & $\mathrm{~N}$ & $\%$ & $\mathrm{~N}$ & $\%$ \\
\hline Low result & 0 & 0,0 & 6 & 19,4 & 6 & 19,4 \\
\hline Average result & 3 & 9,7 & 19 & 61,3 & 22 & 71,0 \\
\hline High Result & 1 & 3,2 & 2 & 6,5 & 3 & 9,7 \\
\hline Total & 4 & 12,9 & 27 & 87,1 & 31 & 100,0 \\
\hline
\end{tabular}


The majority of subjects, both women $(9,7 \%)$ and men $(61,3 \%)$, got an average result for the "Positive attitude" strategy (Table 6). It can, therefore, be assumed that in difficult situations they cannot provide an optimistic and hopeful assessment. Their attitude to life is not positive. Every fourth woman $(3,2 \%)$ and every fourteenth man $(6,5 \%)$, in turn, got a high result, which means that in a difficult situation they are full of hope and optimism and try to notice the bright side of the problem. The remaining group, that is every fourth man $(19,4 \%)$ obtained low results, which shows their negative attitude to life, lack of hope and pessimism in the face of a problem. Generally speaking, the results show that both men and women use the strategy of positive attitude to a similar extent. They adapt to the encountered problems and hope for their successful solution.

Table 7.

Ways of coping with respect to the "Blaming oneself" variable

\begin{tabular}{|c|c|c|c|c|c|c|}
\hline \multirow{2}{*}{ Results } & \multicolumn{9}{|c|}{ Sex } \\
\cline { 2 - 7 } & \multicolumn{2}{|c|}{ Women } & \multicolumn{2}{c|}{ Men } & \multicolumn{2}{c|}{ Total } \\
\cline { 2 - 7 } & $\mathrm{N}$ & $\%$ & $\mathrm{~N}$ & $\%$ & $\mathrm{~N}$ & $\%$ \\
\hline Low result & 0 & 0,0 & 6 & 19,4 & $\mathbf{6}$ & 19,4 \\
\hline Average result & 4 & 12,9 & 17 & 54,8 & 21 & 67,7 \\
\hline High Result & 0 & 0,0 & 4 & 12,9 & 4 & 12,9 \\
\hline Total & 4 & 12,9 & 27 & 87,1 & 31 & 100,0 \\
\hline
\end{tabular}

For the strategy "Blaming oneself", all the women $(12,9 \%)$ and the majority of men $(54,8 \%)$ got average results. It means that in difficult situations they generally do not indulge in self-criticism and do not blame themselves for the situation. Every seventh man (12,9\%), in turn, got a high result, which means that they have a tendency to take the blame and selfcriticise. Low results for this strategy were obtained by every fourth man $(19,4 \%)$, which means that, in general, they do not feel responsible for the situations they find themselves in. 
Table 8.

Ways of coping with respect to the "Reduction of tension" variable

\begin{tabular}{|c|c|c|c|c|c|c|}
\hline \multirow{2}{*}{ Results } & \multicolumn{6}{|c|}{ Sex } \\
\cline { 2 - 7 } & \multicolumn{2}{|c|}{ Women } & \multicolumn{2}{c|}{ Men } & \multicolumn{2}{c|}{ Total } \\
\cline { 2 - 7 } & N & $\%$ & N & $\%$ & N & $\%$ \\
\hline Low result & 0 & 0,0 & 10 & 32,3 & 10 & 32,3 \\
\hline Average result & 3 & 9,7 & 16 & 51,6 & 19 & 61,3 \\
\hline High Result & 1 & 3,2 & 1 & 3,2 & 2 & 6,5 \\
\hline Total & 4 & 12,9 & 27 & 87,1 & 31 & 100,0 \\
\hline
\end{tabular}

Similarly to other strategies, in the case of "Reduction of tension", almost all women $(9,7 \%)$ and the majority of men $(51,6 \%)$ got average results (Table 8). It may therefore seem that in a problematic situation they reduce their stress in normal ways, sometimes by physical effort and rest, in other cases by excessive eating and stimulants. High results were obtained by a quarter of women $(3,2 \%)$ and only every twenty seventh man $(3,2 \%)$. These people tend to alleviate the tension by physical exercise in the gym, jogging, or by excessive eating, drinking alcohol or using drugs. Low results were obtained only by every third man (32,3\%), which points to the opposite kinds of behavior than the previous group. It can, therefore, be said that the subjects, both men and women, reduce tension in stressful situations in similar ways.

Table 9.

Ways of coping with respect to the "Retiring into oneself" variable

\begin{tabular}{|c|c|c|c|c|c|c|}
\hline \multirow{2}{*}{ Results } & \multicolumn{9}{|c|}{ Sex } \\
\cline { 2 - 8 } & \multicolumn{2}{|c|}{ Women } & \multicolumn{2}{c|}{ Men } & \multicolumn{2}{c|}{ Total } \\
\cline { 2 - 8 } & N & $\%$ & N & $\%$ & N & $\%$ \\
\hline Low result & 0 & 0,0 & 5 & 16,1 & 5 & 16,1 \\
\hline Average result & 3 & 9,7 & 22 & 71,0 & 25 & 80,6 \\
\hline High Result & 1 & 3,2 & 0 & 0,0 & 1 & 3,2 \\
\hline Total & 4 & 12,9 & 27 & 87,1 & 31 & 100,0 \\
\hline
\end{tabular}


On the scale of "Retiring into oneself" strategy, both women $(9,7 \%)$ and men $(71 \%)$ mainly got average results (Table 9$)$. So, it can be claimed that in stressful situations, they do not restrain their feelings, do not clam up but look for contact with the environment. High results, which are characterized by secretiveness, clamming up, restraining feelings and isolation from the closest family were obtained only by a quarter of women $(3,2 \%)$. Low results, in turn, which reflect expressing feelings and emotions, openness and lack of isolation from the environment, were obtained by a fifth of men $(16,1 \%)$. Therefore, it can be claimed that both men and women react similarly to problematic situations.

In order to get more precise results, a comparative analysis was carried out with the use of t-Student test for independent groups, taking into consideration variables such as sex and the place of living.

Table 10.

Strategies of coping with difficult situations for the subjects - according to sex

\begin{tabular}{|c|c|c|c|c|c|c|}
\hline \multirow{3}{*}{ Variable } & \multicolumn{4}{|c|}{ Group } & \multirow{2}{*}{\multicolumn{2}{|c|}{$\begin{array}{l}\text { Comparison of } \\
\text { average values }\end{array}$}} \\
\hline & \multicolumn{2}{|c|}{ „W" } & \multicolumn{2}{|c|}{ „M” } & & \\
\hline & M & SD & M & SD & $t^{\circ}$ & $\mathrm{p}$ \\
\hline Solving problems & 18,50 & 2,08 & 16,96 & 5,35 & 0,56 & 0,57 \\
\hline Desires & 6,50 & 3,41 & 7,33 & 3,47 & $-0,44$ & 0,65 \\
\hline Objectivity & 6,25 & 3,09 & 7,66 & 2,74 & $-0,94$ & 0,35 \\
\hline Seeking social support & 11,25 & 2,87 & 9,40 & 3,78 & 0,92 & 0,36 \\
\hline Possitive attitude & 4,00 & 2,16 & 5,40 & 2,43 & $-1,08$ & 0,28 \\
\hline Blaming oneself & 4,00 & 0,00 & 4,29 & 2,44 & $-0,23$ & 0,81 \\
\hline Reduction of tension & 4,50 & 2,081 & 3,14 & 2,29 & 1,10 & 0,27 \\
\hline Retiring into oneself & 2,75 & 1,25 & 3,96 & 1,97 & $-1,18$ & 0,24 \\
\hline
\end{tabular}

Explanations: $W$ - women, $M-$ men, $S D$ - standard deviation, $t-t$-Student's test value, $p<0,05$ statistical significance. 
The analysis of the data in Table 10 shows that sex does not differentiate the group of subjects in any way that is statistically significant $(\mathrm{p}<0,05)$. Nevertheless, some differences in results can be noticed. Average results of men are slightly higher for the following strategies: "Desires" $(M=7,33$; $\mathrm{W}=6,50)$, "Passive attitude" ( $M=7,66 ; \mathrm{W}=6,25)$, "Positive attitude" $(M=5,40$; $\mathrm{W}=4,00)$, "Blaming oneself" $(\mathrm{M}=4,29 ; \mathrm{W}=4,00)$ and "Retiring into oneself" $(\mathrm{M}=3,96 ; \mathrm{W}=2,75)$. Women, in turn, handle better such strategies as "Solving problems" (W=18,50; $M=16,96)$, "Seeking social support" $(W=11,25 ; M=9,40)$ and "Reduction of tension" ( $\mathrm{W}=4,50 ; \mathrm{M}=3,14)$. In all the cases, however, no significant differences can be noticed.

Table 11.

Strategies of coping with difficult situations for the subjects - according to the place of living

\begin{tabular}{|c|c|c|c|c|c|c|}
\hline \multirow{2}{*}{ Variable } & \multicolumn{4}{|c|}{ Group } & \multicolumn{2}{c|}{$\begin{array}{c}\text { Comparison of } \\
\text { average values }\end{array}$} \\
\cline { 2 - 7 } & \multicolumn{2}{|c|}{ „M" } & \multicolumn{2}{c|}{ „W” } & \multicolumn{2}{c|}{} \\
\cline { 2 - 7 } & M & SD & M & SD & $\mathbf{t}^{\circ}$ & p \\
\hline Solving problems & 17,36 & 4,37 & 16,83 & 6,19 & 0,28 & 0,77 \\
\hline Desires & 8,00 & 3,75 & 6,00 & 2,48 & 1,62 & 0,11 \\
\hline Objectivity & 7,26 & 2,66 & 7,83 & 3,04 & $-0,54$ & 0,58 \\
\hline Seeking social support & 9,63 & 4,04 & 9,66 & 3,22 & $-0,02$ & 0,97 \\
\hline Possitive attitude & 5,73 & 2,28 & 4,41 & 2,50 & 1,51 & 0,14 \\
\hline Blaming oneself & 4,57 & 1,83 & 3,75 & 2,86 & 0,98 & 0,33 \\
\hline Reduction of tension & 3,08 & 1,92 & 4,08 & 2,67 & $-1,00$ & 0,14 \\
\hline Retiring into oneself & 3,52 & 1,74 & 4,25 & 2,17 & $-1,02$ & 0,31 \\
\hline
\end{tabular}

Explanations: $W$ - women, $M-$ men, $S D$ - standard deviation, $t-t$-Student's test value, $p<0,05$ statistical significance.

Similar situation can be found in the case of the place of living (Table 11). It does not differentiate the group of subjects in any statistically significant way $(\mathrm{p}<0,05)$. Only slight differences in the averages could be found. The 
subjects living in cities got higher results for the following strategies: "Solving problems" ( $M=17,36 ; \mathrm{W}=16,83)$, "Desires" $(\mathrm{M}=8,00 ; \mathrm{W}=6,00)$, "Positive attitude" (M=5,73; W=4,41) and "Blaming oneself" $(M=4,57$; $\mathrm{W}=3,75)$. The subjects living in rural communities have a bigger tendency to use the strategies such as "Objectivity" (W=7,83; $M=7,26)$, "Seeking social support" (W=9,66; $M=9,63)$, "Reduction of tension" ( $W=4,08 ; M=3,08)$ and "Retiring into oneself" ( $\mathrm{W}=4,25 ; \mathrm{M}=3,52)$. The differences, however, are not significant.

\section{Conclusions}

Generally speaking, the subjects of the study do not seem to prefer any of the eight analyzed ways of coping with problematic situations, which is confirmed by the average results obtained for all the strategies. More specifically, however, it can be noticed that men tend to employ the strategy of rational approach to problems more than women. But they also tend to be more passive than women, wait for a miracle and escape to the dream world. Male subjects, more frequently than their female colleagues, try to take an objective perspective on the situation, but also look for support in prayer and with other people. The women that took part in the study more frequently adopt irrational approach to problems, but they still employ this strategy with moderation. Both men and women to a similar extent use the strategy of positive attitude and adopt an optimistic approach to the problems hoping to achieve a quick and desired solution. It can, however, be noticed that men have slightly bigger tendency to a negative, pessimistic approach to life. Women moderately blame themselves for the situation they found themselves in and men more often tend to take the blame, punish and criticize themselves in the most difficult circumstances. Both male and female subjects to a similar extent reduce the tension that arises in the face of problems. It can, however, be noticed that men more rarely do so by doing physical exercise, rest, excessive eating, using stimulants or smoking. What is more, women more frequently than men use the strategy of retiring into oneself. As a result, they are more secretive and tend to bottle up feelings and emotions connected with stress, which causes greater mental strain that is not helpful when solving problems. 
The analyses also show that the variables such as sex and place of living do not significantly influence the subjects' preferences with respect to the ways of coping with difficult situations.

It is commonly known that working in tourism industry, as a foreign excursion guide, involves frequent encounters with difficult and problematic situations. As a result, the employees are undoubtedly a group of high risk due to their exposure to long, negative and strong emotional states, which combined with other objective factors may lead to serious health problems. Everyday duties and contacts with demanding customers make every guide choose individual ways of reducing tension depending on the situation they find themselves in. Neither their sex, nor the place of living influence their choice. Working in tourism is demanding so foreign excursion guides must possess some psychological resources that allow them to alleviate the tension and cope with problematic situations. What is crucial is their personality, which manifests itself not only in the attitude to professional duties but also to other people. After all, it is known that optimism and good sense of humor combined with empathy, tact and tolerance allow reducing tension, gain trust and respect of other people. Such character traits allow solving problems and conflicts before they escalate.

To sum up, it can be said the group of tour guides that took part in the study handles problematic situations quite well. They may not prefer any of the analyzed strategies but they use all of them on similar level. As a result, they can be said to fulfill their professional duties without harm to their health.

It needs to be remembered, however, that the piece of research presented in this paper covers just a small portion of the broad research field which is coping with difficult situations. It would be interesting to continue the analyses with bigger sample and greater number of variables. 


\section{References:}

Bargiel-Matusiewicz K., Podbielski Z., Klasik A. (2004). Współczesne rozumienie stresu. „Wiadomości Lekarskie”, vol. 57, issue 3-4, p. 188-192, ISSN: 0043-5147

Brzeziński J. Elementy metodologii badań psychologicznych. Warszawa PWN, wyd. 2, 1980 ISBN: 8301017007

Heszen-Niejodek I. Styl radzenia sobie ze stresem jako indywidualna zmienna wptywająca na funkcjonowanie w sytuacji stresowej. In: J. Strelau (ed.) Osobowość a ekstremalny stres (238-263). Gdańsk, pp. 238-263. Gdańskie Wydawnictwo Psychologiczne 2000.

Kirenko J. (1998). Psychospołeczne determinanty funkcjonowania seksualnego osób $z$ uszkodzeniem rdzenia kręgowego. Wydawnictwo UMCS Lublin. ISBN: 83-2271146-8

Lazarus R.S., Folkman S. (1984). Stress, appraisal and coping. New York. Springer ISBN13: 9780826141910

Łobocki M. (2007). Wprowadzenie do metodologii badań pedagogicznych. Kraków. ISBN: 978-83-7308-852-8

Nowak S. (2006). Metodologia badań społecznych. Wydawnictwo Naukowe PWN Warszawa. ISBN: 830114999X

Pilch T. (1998). Zasady badań pedagogicznych, Warszawa: Wydawnictwo Akademickie „Żak”, Wyd. 2 popr. i rozszerz. ISBN : 8386770007

Strelau J. (ed.) (2000). Psychologia. Podręcznik akademicki. Gdańskie Wydawnictwo Psychologiczne, ISBN: 8387957054

Strelau J., Jaworowska A., Wrześniewski K., Szczepaniak P. (2005). Kwestionariusz Radzenia Sobie w Sytuacjach Stresowych CISS. Warszawa : Pracownia Testów Psychologicznych Polskiego Towarzystwa Psychologicznego, Wyd. 2 niezmienione, ISBN: 9788360733578

Strelau J., Zawadzki B., Oniszczenko W., Sobolewski A., Bieniek A. (2004). Diagnoza zespolu stresu pourazowego: charakterystyka wersji czynnikowej i klinicznej kwestionariusza PTSD. In: J. Strelau (ed.) Osobowość a ekstremalny stres, pp. 220-237, Gdańskie Wydawnictwo Psychologiczne, ISBN: 83-89120-89-5

Terelak J.F. (2008). Człowiek i stres. Bydgoszcz-Warszawa. ISBN: 978-83-6018673-2

Wosik-Kawala D. (2013). Rozwijanie kompetencji emocjonalnych uczniów szkół ponadgimnazjalnych. Wydawnictwo UMCS Lublin, ISBN: 978-83-7784-377-2 
